\author{
Volume 1, Nomor 1, Juni 2020, Hal 43-55 \\ INFOTECH: Jurnal Informatika \& Teknologi \\ p ISSN 2722-9378 | e ISSN 2722-9386
}

\title{
SISTEM PENDUKUNG KEPUTUSAN PENENTUAN BANTUAN UNTUK KELUARGA MISKIN MENGGUNAKAN TEKNIK ANALISIS HIRARKI PROSES
}

\author{
Iman Aripin ${ }^{1 *}$, Pria Sukamto $^{2}$, Nurkholis $^{3}$ \\ $1^{*}, 2,3$ Program Studi Teknik Informatika, Sekolah Tinggi Teknologi Muhammadiyah Cileungsi. \\ $1^{*}, 2,3$ Jl. Anggrek No.25, Perum. PTSC, Cileungsi, Bogor, Jawa Barat, Indonesia 16820
}

\begin{tabular}{l} 
Informasi Artikel \\
\hline Article History \\
Submission: $25-05-2020$ \\
Revised: $15-06-2020$ \\
Accepted: $25-06-2020$ \\
Published: $30-06-2020$
\end{tabular}

Kata Kunci:

AHP, Database. Pra-

Sejahtera, Support System.

Keywords:

AHP, Database. Pre-

prosperous, Support System.

* Korespondensi:

Iman Aripin

arifinstreetcore@gmail.com

\begin{abstract}
Abstrak
Desa XYZ salah satu desa yang masih perlu mendapatkan bantuan untuk warganya karena penduduk desa tersebut masih ada warganya dalam kategori pra-sejahtera, namun permasalahannya yang sering terjadi bahwa bantuan tersebut masih kadang-kadang kurang tepat sasaran pada keluarga yang tidak berhak menerimanya. Permasalahan tersebut dikarenakan perangkat yang terkait dalam pengambilan keputusan untuk menentukan prioritas penerima bantuan yang digunakan hanya berpatokan pada pengajuan dari Rukun Tetangga (RT) dan Rukun Warga (RW) saja tanpa adanya pertimbangan kriteria-kriteria untuk pengambilan keputusan sehingga rentan terjadinya kesalahan dalam memprioritaskan bantuan bagi warga yang lebih membutuhkan untuk segera mendapat bantuan tersebut. Salah satu tindakan untuk menyelesaikan masalah ini adalah dengan dibangunnya aplikasi sistem pendukung keputusan dengan metode AHP dalam mengelola data penduduk terkait layak dan tidak layak menerima bantuan tersebut. Pengujian sistem menggunakan ISO 25010, aplikasi pihak ketiga, dan juga 20 responden dari lingkungan yang berbeda, dari hasil pengujian tersebut aplikasi sistem pendukung keputusan penentuan prioritas penerima bantuan menggunakan metode AHP untuk warga Desa XYZ, Klapanunggal masuk kedalam kategori "Baik" sehingga layak untuk digunakan sebagai alat untuk menentukan prioritas penerima bantuan. Sistem ini selanjutnya bisa dimanfaatkan oleh perangkat desa untuk menentukan layak tidaknya seorang warga untuk menerima bantuan sehingga tidak terjadi kesalahan.

\section{DECISION SUPPORT SYSTEM FOR DETERMINATION OF ASSISTANCE FOR THE POOR FAMILY USING HIRARKI ANALYSIS TECHNIQUES}

Abstract
XYZ village is one of the villages that still needs help for its residents
because the villagers still have residents in the pre-prosperous category,
but the problem often occurs is that the assistance is still sometimes not
well targeted at families who are not entitled to receive it. These
problems are due to the tools involved in making decisions to determine
\end{abstract}


Sistem Pendukung Keputusan Penentuan Prioritas Bantuan Kepada Warga Kurang

Mampu Menggunakan Teknik Analisis Hirarki Proses

the priority of aid recipients that are used only based on the submission from the Neighborhood Association (RT) and the Community Association (RW) alone without consideration of the criteria for decision making so vulnerable to errors in prioritizing assistance for residents who are more in need to get the assistance immediately. One of the actions to solve this problem is the construction of a decision support system application using the AHP method in managing population data related to the feasible and not deserving of assistance. System testing uses ISO 25010, third party applications, and also 20 respondents from different environments. From the test results the decision support system application determines the priority of beneficiaries using the AHP method for XYZ Village residents, Klapanunggal is included in the "Good" category so that it is suitable for use as a tool to determine the priority of beneficiaries. This system can then be utilized by village officials to determine whether or not a citizen is eligible to receive assistance so that mistakes do not occur.

\section{PENDAHULUAN}

Sebuah lokasi yang berada di lokasi ujung timur kabupaten Bogor yang merupakan daerah pedesaan yang masyarakatnya masih banyak yang hidup dalam kemiskinan. Pemerintah pusat setiap tahunnya memberikan bantuan berupa fasilitas kesehatan, pendidikan, pangan dan masih banyak lagi bantuan lainnya kepada masyarakat yang disalurkan melalui pemerintahan Desa XYZ, Kecamatan Klapanunggal, Kabupaten Bogor. Dalam penyaluran bantuan tersebut pemerintah Desa XYZ melakukan pendataan penduduk keluarga miskin yang dilakukan oleh Rukun Tetangga (RT) dan Rukun Warga (RW) sekitar, terkadang data keluarga miskin yang masuk dari RT dan RW dengan jumlah bantuan yang diberikan pemerintah pusat tidak seimbang, karena banyaknya keluarga miskin yang ada dan terbatasnya bantuan yang diterima. Metode penentuan prioritas penerima bantuan keluarga miskin yang digunakan oleh pemerintah Desa XYZ masih dengan cara menerima pengajuan yang diajukan RT dan RW setempat tanpa mempertimbangkan kriteria pendukung lainnya yang berakibat kurang tepat sasarannya penerima bantuan dari pemerintah.

Dari masalah tersebut diperlukan sistem pendukung keputusan untuk membantu dalam mengambil keputusan untuk penentuan prioritas penerima bantuan keluarga miskin secara spesifik dan perbandingan kriteria pendukung agar bantuan yang diterima tepat sasaran. Maka dengan ini penulis ingin mengembangkan aplikasi pendukung keputusan penentuan keluarga miskin agar bisa mempermudah dalam pengambilan keputusan. Banyak faktor yang mempengaruhi kemiskinan tersebut diantaranya tingkat pendidikan yang masih rendah, kurangnya keahlian yang dimiliki dan juga lapangan pekerjaan yang sangat sulit. Kemiskinan masih banyak terjadi khususnya di daerah terpencil dan pedesaan. 
Kemiskinan suatu keterbatasan yang disandang oleh seseorang, sebuah keluarga, sebuah komunitas, atau bahkan sebuah negara yang menyebabkan ketidak nyamanan dalam kehidupan, terancamnya penegakan hukum dan keadilan, terancamnya bargaining (posisi tawar) dalam pergaulan dunia, hilangnya generasi serta suramnya masa depan bangsa dan negara [1].

Kemiskinan terkait dengan masalah kekurangan pangan dan gizi, keterbelakangan pendidikan, kriminalitas, pengangguran, prostitusi dan masalah-masalah lain yang bersumber dari rendahnya tingkat pendapatan perkapita penduduk. Sistem pendukung keputusan ini nantinya diharapkan dapat membantu perangkat Desa XYZ khususnya dalam memilih warga yang berhak menerima bantuan.

\section{METODE}

Dalam penelitian ini dengan pada warga Desa XYZ, Kecamatan Klapanunggal, Kabupaten Bogor, pada tanggal 01 Februari 2018 - 30 Maret 2018, salah satu metode yang mengedepankan analisis proses secara hirarki adalah menggunakan metode AHP, pemilihan metode untuk analisis permasalahan yang ada di Desa XYZ karena analisis dengan metode AHP tersebut bisa menyusun prioritas dari berbagai alternatif yang komplek dari berbagai kriteria yang komplek dan multi kriteria. Adapun skema penelitian menggunakan metode AHP seperti pada gambar 1.

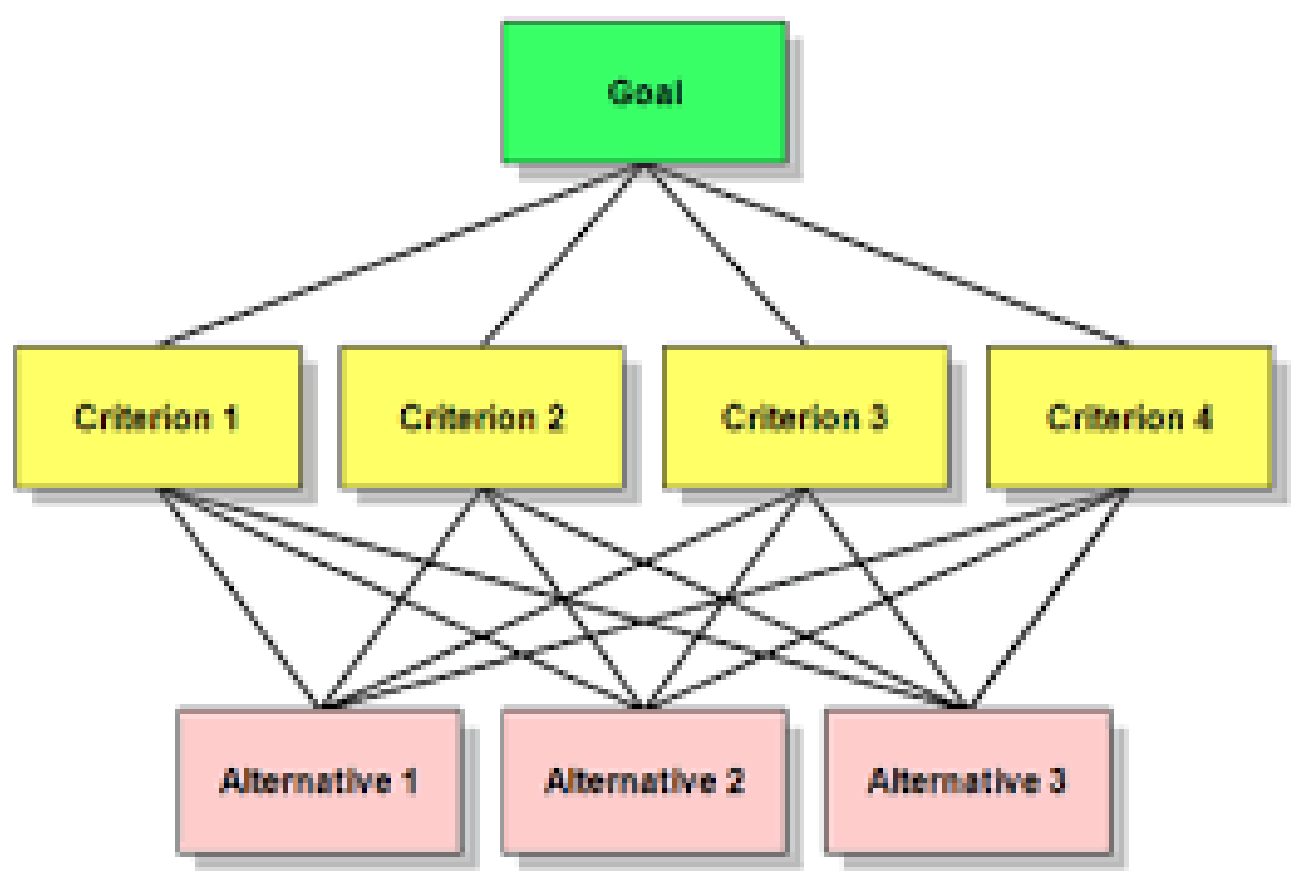

\subsection{Kemiskinan}

Gambar 1. Skema diagram AHP [2]

Kemiskinan adalah keadaan serba kekurangan yang dialami oleh seseorang atau sekelompok orang diluar keinginan yang bersangkutan sebagai kejadian yang tidak dapat dihindari dengan kekuatan yang dimiliki. Kondisi ini disebabkan berbagai faktor yang 
Sistem Pendukung Keputusan Penentuan Prioritas Bantuan Kepada Warga Kurang

Mampu Menggunakan Teknik Analisis Hirarki Proses

sangat kompleks yang berinteraksi satu sama lain sehingga menghasilkan kondisi baru yang menyebabkan kemiskinan[3].

\subsection{Definisi Sistem}

Sistem merupakan kumpulan elemen yang saling berkaitan yang bertanggung jawab memproses masukan (input) sehingga menghasilkan keluaran (output)[4].

Definisi Sistem menurut (Edhy Susanta, 2003) dimana "Sistem dapat didefinisikan berupa bagian-bagian dalam suatu kegiatan atau proses suatu sistem yang saling terhubung untuk tujuan yang sama mencapai tujuan.

\subsection{Definisi Keputusan}

Menurut [5], keputusan adalah suatu proses dalam memilih cara dan strategi terhadap suatu tindakan mengatasi masalah tersebut. Tindakan dalam memilih cara atau metode yang bisa melakukan dalam mencari alternatif terbaik dalam mengambil suatu keputusan. Dimana tujuan dari keputusan sendiri adalah sasaran tindakan tertentu yang merupakan alternatif dari berbagai alternatif terbaik dilakukan oleh pengambil keputusan. Adapun karakteristik dari suatu keputusan.

a. Banyak pilihan atau alternatif.

b. Diperlukan persyaratan atau tidak.

c. Mengadopsi suatu pola tindakan atau model tindakan baik secara terstruktur maupun tidak secara terstruktur.

d. Banyak input atau variable.

e. Ada faktor resiko.

f. Membutuhkan kecepatan, target dan akurat

\subsection{Sistem Pendukung Keputusan (SPK)}

SPK adalah kepanjangan dari sistem Pendukung Keputusan dalam menyediakan sistem informasi yang informatif terkait alternatif-alternatif yang terbaik secara matematis dan lebih terstruktur sehingga menjadi alat bantu yang baik dalam pengambilan suatu keputusan oleh pihak yang berwenang [6]. Dimana kriteria terkait suatu Sistem Pendukung Keputusan (SPK).

a. Memberikan panduan dukungan pada pihak pengambil keputusan

b. Adanya interaksi melalui interface antara user dengan mesin/komputer dimana manusia (user) sebagai kendali utama pengambil keputusan.

c. Dapat menjadi acuan dalam pengambilan keputusan yang terstruktur atau semi terstruktur dan menjadi pengambilan keputusan yang saling terintegrasi antara beberapa alternatif.

d. Menjadikan sebagai bahan dalam proses dialog dalam menggali informasi sesuai dengan kebutuhan dalam pengambilan keputusan.

e. Memiliki sub sistem yang saling keterkaitan sehingga merupakan komponen dalam kesatuan sistem secara utuh.

f. Data dan model merupakan komponen utama dalam mengambil keputusan [7]. 


\subsection{Metode Analytic Hierarchy Process (AHP)}

Metode AHP adalah metode dalam mengambil keputusan dengan cara menguraikan masalah dengan banyak faktor/kriteria secara komplek menjadi suatu hasil yang hirarki.

AHP merupakan teknik pengambilan keputusan/optimasi multivariate yang digunakan dalam analisa kebijaksanaan. Pada hakekatnya AHP merupakan suatu bentuk dari model yang komprehensif dalam pengambilan keputusan baik secara kualitatif maupun secara kuantitatif [8].

\subsection{Proses Perhitungan}

Berikut ini adalah perhitungan metode AHP meliputi beberapa langkah, berikut di bawah ini langkah-langkah perhitungan metode AHP [9].

1. Menyiapkan matrik berpasangan untuk nilai kuesioner.

Penilaian dilakukan dengan skor 1 sampai 9 pada perbandingan ini berlaku aksioma reciprocal.

2. Penjumlahan matriks perbandingan berpasangan, setiap baris dari matriks perbandingan berpasangan dijumlahkan masing-masing kriteria berpasangan.

3. Pencarian nilai prioritas, nilai prioritas didapat dengan cara membagi eigen vector dengan banyaknya jumlah elemen kriteria yang ada. Oleh sebab itu, untuk mencari nilai eigen dan vektor eigen suatu matriks interval diperlukan suatu metode numerik yaitu dengan menggunakan metode pangkat [10].

4. Jika $A$ adalah sebuah matriks $n \times n$, maka sebuah vektor tak nol $\mathbf{v}$ pada $\boldsymbol{R}^{n}$ disebut vektor eigen (eigenvector) dari $A$ jika $A \mathbf{v}$ adalah sebuah kelipatan skalar dari $\mathbf{v}$ [11].

$$
A \mathbf{v}=\lambda \mathbf{v}
$$

Untuk sebarang skalar $\lambda$. Skalar $\lambda$ disebut nilai eigen (eigen value) dari $A$, dan $\mathbf{v}$ disebut sebagai vektor eigen dari $A$ yang bersesuaian dengan $\lambda$. Metode pangkat menghasilkan sebuah aproksimasi terhadap nilai eigen terbesar dan vektor eigen yang bersesuaian [12].

\section{A. Eigen vector}

Emaks $=£$ kriteria $1+\ldots \ldots+£$ kriteria $n$

- $\quad$ Emaks = eigen vector

- $\quad$ E kriteria $=$ nilai bobot kriteria

- $\quad \mathrm{n}=$ jumlah kriteria kemudian menguji konsistensinya $(\boldsymbol{C} \boldsymbol{I}$

B. Consistency Index

$C I=(£$ maks-n $) / \mathrm{n}$

- $\quad C I=$ Consistency Index

- $\quad \mathrm{n}=$ jumlah kriteria

- $\quad €$ maks = Eigen vector maksimum.

5. Menghitung konsistensi.

$\mathrm{CR}=\mathrm{CI} / \mathrm{IR}$ 
Sistem Pendukung Keputusan Penentuan Prioritas Bantuan Kepada Warga Kurang

Mampu Menggunakan Teknik Analisis Hirarki Proses

$\mathrm{Cr}=$ Consistency Ratio

- $\quad C i=$ Consistency Index

- $\quad R i=$ Index Random Consistency

\section{HASIL DAN PEMBAHASAN}

Implementasi pada aplikasi sistem pendukung keputusan penentuan prioritas penerima bantuan ini hanya digunakan pada lingkungan Desa XYZ saja untuk menentukan prioritas penerima bantuan bagi keluarga miskin secara berkala. Teknik yang digunakan yaitu metode AHP hasil dari keluaran sistem berupa bobot perangkingan dari setiap data KK warga miskin Desa XYZ, sehingga dari perangkingan itu dapat diketahui KK keluarga miskin mana saja yang berhak mendapatkan bantuan sesuai kriteria yang sudah ditentukan di tabel kriteria yang sudah dirumuskan di aplikasi (dari form formulir pendataan calon masyarakat yang menerima bantuan rehabilitasi rumah tidak layak huni).

\subsection{Perangkat Lunak dan Perangkat Keras}

Tahap selanjutnya adalah tahap implementasi ini perangkat lunak dan perangkat keras yang penulis gunakan.

a. Perangkat Lunak.

- Sistem Operasi: Windows 10 Enterprise 64 bit.

- Bahasa Pemrograman: PHP.

- Database: MySQL, Code Editor: Sublime Text dan Apache XAMPP.

b. Perangkat Keras.

- Processor Intel Celeron N3350 (1.1 GHz), RAM 4 GB dan SSD 128GB.

Dengan spesifikasi perangkat keras dan perangkat lunak seperti di atas tersebut, aplikasi masih masih sangat bisa berjalan dengan lancar.

\subsection{Tampilan Aplikasi}

Tampilan dari Sistem pendukung keputusan penentuan prioritas penerima bantuan menggunakan metode AHP berbasis web ini hanya berjalan di localhost saja tidak secara bisa diakses secara online, berikut di bawah ini adalah implementasi tampilan dari aplikasi tersebut.

\subsubsection{Halaman Log In}

Ketika aplikasi pertama kali dibuka tampilan pertama halaman log in, pengguna diminta untuk memasukan nama user dan password yang telah terdaftar dalam database sistem, jika pengguna salah memasukan username dan password sistem akan menampilkan pesan bahwa username dan password tidak cocok, jika pengguna benar memasukan nama pengguna dan password kemudian sistem akan menampilkan beranda utama dari aplikasi. 


\section{Silahkan Masukan Username dan Password Anda}

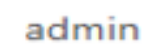

Gambar 2. Halaman log in

\subsubsection{Halaman Beranda Utama}

Setelah pengguna berhasil masuk maka sistem akan menampilkan halaman beranda utama, pada halaman ini menampilkan menu navigasi beranda, tampil data, analisa dan admin. Selain itu pada halaman ini menampilkan grafik batang hasil perangkingan calon penerima bantuan, gambar dokumentasi calon penerima bantuan dan tombol untuk mengubah dalam mode layar penuh.

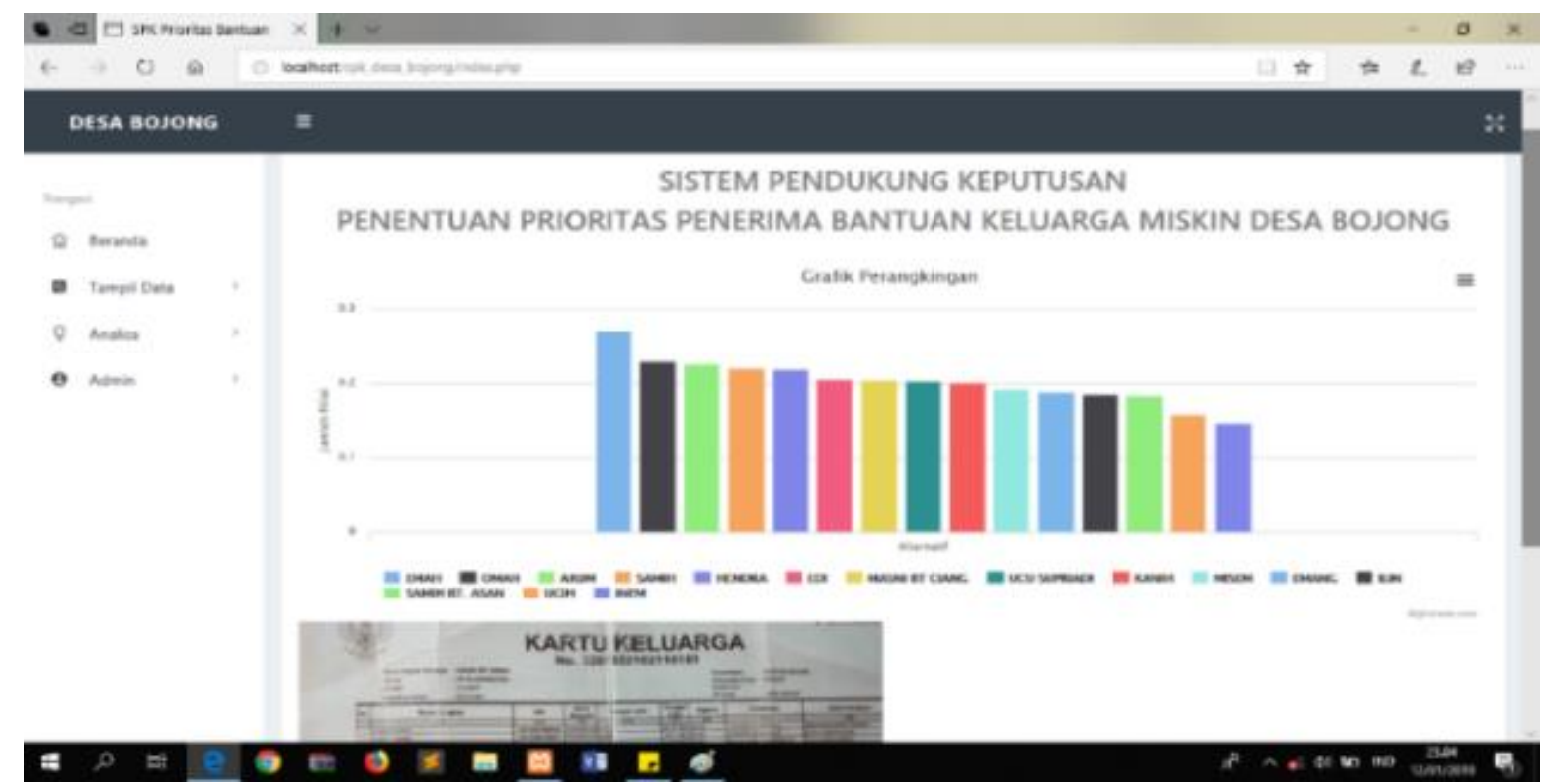

Gambar 3. Beranda utama

Adapun aplikasi ini dilengkapi juga halaman skala nilai, data kriteria, data sub kriteria, data calon penerima bantuan, analisis kriteria, analisa sub kriteria, analisa calon penerima bantuan, perangkingan, laporan dan analisa kriteria. 
Sistem Pendukung Keputusan Penentuan Prioritas Bantuan Kepada Warga Kurang

Mampu Menggunakan Teknik Analisis Hirarki Proses

\subsection{Pengujian Sistem}

Untuk mengetahui fungsi dan kualitas dari perangkat lunak yang telah dibangun diperlukan pengujian perangkat lunak. Pada pengujian perangkat lunak ini menggunakan jenis pengujian perangkat lunak ISO 25010.

\section{Functional Suitability}

Pengukuran dilakukan oleh ahli pemrograman.

$$
X=1-\frac{A}{B}
$$

Dimana:

$X=$ Functionality.

$A=$ Jumlah total fungsi yang tidak valid.

$B=$ Jumlah seluruh fungsi.

Hasil pengujian dari aplikasi.

$$
X=1-\frac{A}{B}=1-\frac{0}{200}=1
$$

Dari hasil pengujian didapat nilai sebesar 1 dimana nilai yang baik menurut interpretasi ISO 25010 yaitu nilai yang mendekati 1 atau sama dengan 1, dengan demikian aplikasi tersebut telah lolos untuk uji Functional Suitability.

2. Performance Efficiency

\begin{tabular}{|c|c|c|c|c|c|c|c|}
\hline \multirow[t]{6}{*}{ Empty Cache } & \multicolumn{3}{|c|}{$\begin{array}{l}\text { HTTP Requests - } 14 \\
\text { Total Weight - 2344.5K }\end{array}$} & \multirow[t]{6}{*}{ Primed Cache } & \multicolumn{3}{|c|}{$\begin{array}{l}\text { HTTP Requests - } 14 \\
\text { Total Weight - 14.3K }\end{array}$} \\
\hline & $\mathbf{\square}$ & 1 HTML/Text & $14.3 \mathrm{~K}$ & & $\mathbf{\square}$ & 1 HTML/Text & $14.3 \mathrm{~K}$ \\
\hline & $\square$ & 6 JavaScript File & $406.7 \mathrm{~K}$ & & $\square$ & 6 JavaScript File & $0.0 \mathrm{~K}$ \\
\hline & 口 & 3 Stylesheet File & $529.9 \mathrm{~K}$ & & $\square$ & 3 Stylesheet File & $0.0 \mathrm{~K}$ \\
\hline & $\square$ & 3 Image & 1392.3K & & 口 & 3 Image & $0.0 \mathrm{~K}$ \\
\hline & $\mathbf{\square}$ & 1 Favicon & $1.1 \mathrm{~K}$ & & $\mathbf{\square}$ & 1 Favicon & $0.0 \mathrm{~K}$ \\
\hline
\end{tabular}

Statistics The page has a total of 14 HTTP requests and a total weight of $2344.5 \mathrm{~K}$ bytes with empty cache

Gambar 4. Statistik pengujian Yslow halaman beranda.

Hasil analisa dan pengujian efficiency menggunakan aplikasi yslow menggunakan browser mozilla firefox dengan total page sebanyak 28 menghasilkan skor terendah 81 (Grade B) dan skor tertinggi 89 (Grade B) dan rata-rata skor yang didapat pada pengujian halaman web menggunakan aplikasi yslow adalah sebesar 84,14 (Grade B), dapat dikatakan aplikasi tersebut memiliki tingkat performance efficiency yang cukup baik.

Tabel 1. Hasil Pengujian Yslow

\begin{tabular}{lcc}
\hline Halaman & Grade & Skor \\
\hline Log In & $\mathrm{B}$ & 88 \\
Index & $\mathrm{B}$ & 82 \\
Tampil Nilai & $\mathrm{B}$ & 83
\end{tabular}




\begin{tabular}{lll} 
Input Nilai & B & 85 \\
Update Nilai & B & 83 \\
Tampil Kriteria & B & 83 \\
Input Kriteria & B & 85 \\
Update Kriteria & $\mathrm{B}$ & 85 \\
Tampil Sub Kriteria & $\mathrm{B}$ & 83 \\
Input Sub Kriteria & $\mathrm{B}$ & 85 \\
Update Sub Kriteria & $\mathrm{B}$ & 85 \\
Tampil Data Diri & $\mathrm{B}$ & 83 \\
Input Data Diri & $\mathrm{B}$ & 81 \\
Update Data Diri & $\mathrm{B}$ & 85 \\
Tampil Gambar & $\mathrm{B}$ & 81 \\
Input Gambar & $\mathrm{B}$ & 82 \\
Update Gambar & $\mathrm{B}$ & 82 \\
Tampil Analisa Kriteria & $\mathrm{B}$ & 83 \\
Hasil Analisa Kriteria & $\mathrm{B}$ & 89 \\
Tampil Analisa Sub & $\mathrm{B}$ & 85 \\
Kriteria & & \\
Hasil Analisa Sub Kriteria & $\mathrm{B}$ & 89 \\
Analisa Keluarga Miskin & $\mathrm{B}$ & 81 \\
Penilaian Bantuan & $\mathrm{B}$ & 85 \\
Rangking & $\mathrm{B}$ & 85 \\
Daftar Pengguna & $\mathrm{B}$ & 83 \\
Input Pengguna & $\mathrm{B}$ & 85 \\
Update Pengguna & $\mathrm{B}$ & 85 \\
Laporan & $\mathrm{B}$ & 85 \\
\hline
\end{tabular}

3. Usability

Untuk pengujian usability menggunakan responden yang berjumlah 20 orang dan disebar di lingkungan kerja Kantor Desa XYZ, sesuai tabel 2.

Tabel 2. Daftar responden.

\begin{tabular}{ccc}
\hline No & Jenis Kelamin & Jumlah \\
\hline 1. & Laki-laki & 14 \\
2. & Perempuan & 6 \\
& Total Responden & 20 \\
\hline
\end{tabular}

Dalam penggunaan metode kuisioner menggunakan model kuesioner yang digunakan adalah kuesioner $S U P R-Q$ yang terdiri dari 8 pertanyaan. Untuk pertanyaan satu sampai tujuh menggunakan 5 poin skala likert, dan pertanyaan kedelapan 
menggunakan skala likert 10 poin, untuk pertanyaan kedelapan nilainya adalah $1 / 2$ dari nilai yang didapat.

Tabel 3. Penilaian kuisioner usability

\begin{tabular}{cccccccccccc}
\hline \multirow{2}{*}{ Responden } & \multicolumn{1}{c}{ Butir Soal } & \multicolumn{1}{c}{ Jumlah } & Jumlah & Total Jumlah \\
& 1 & 2 & 3 & 4 & 5 & 6 & 7 & 8 & Soal 1-7 & Soal 8 & Nilai \\
\hline 1 & 4 & 3 & 5 & 4 & 3 & 2 & 4 & 8 & 25 & 4 & 29 \\
2 & 3 & 3 & 5 & 4 & 3 & 5 & 2 & 7 & 25 & 3,5 & 28,5 \\
3 & 4 & 2 & 4 & 4 & 3 & 4 & 5 & 8 & 26 & 4 & 30 \\
4 & 5 & 4 & 5 & 4 & 5 & 5 & 5 & 10 & 33 & 5 & 38 \\
5 & 4 & 3 & 5 & 5 & 5 & 4 & 5 & 10 & 31 & 5 & 36 \\
6 & 3 & 3 & 4 & 4 & 3 & 3 & 4 & 9 & 24 & 4,5 & 28,5 \\
7 & 4 & 5 & 5 & 4 & 5 & 5 & 4 & 9 & 32 & 4,5 & 36,5 \\
8 & 4 & 5 & 5 & 4 & 5 & 5 & 4 & 9 & 32 & 4,5 & 36,5 \\
9 & 4 & 5 & 5 & 4 & 5 & 5 & 4 & 9 & 32 & 4,5 & 36,5 \\
10 & 5 & 5 & 5 & 5 & 5 & 4 & 5 & 10 & 34 & 5 & 39 \\
11 & 2 & 3 & 3 & 4 & 3 & 3 & 4 & 7 & 22 & 3,5 & 25,5 \\
12 & 3 & 4 & 2 & 4 & 5 & 4 & 5 & 5 & 27 & 2,5 & 29,5 \\
13 & 3 & 3 & 3 & 4 & 4 & 3 & 3 & 6 & 23 & 3 & 26 \\
14 & 3 & 3 & 3 & 3 & 4 & 4 & 4 & 8 & 24 & 4 & 28 \\
15 & 3 & 4 & 3 & 3 & 4 & 3 & 4 & 6 & 24 & 3 & 27 \\
16 & 4 & 4 & 5 & 5 & 4 & 4 & 5 & 8 & 31 & 4 & 35 \\
17 & 4 & 3 & 5 & 5 & 2 & 3 & 4 & 6 & 26 & 3 & 29 \\
18 & 5 & 4 & 3 & 4 & 3 & 4 & 5 & 9 & 28 & 4,5 & 32,5 \\
19 & 5 & 4 & 5 & 4 & 5 & 4 & 3 & 9 & 30 & 4,5 & 34,5 \\
20 & 4 & 4 & 5 & 5 & 5 & 5 & 5 & 10 & 33 & 5 & 38 \\
\hline & & & Total & Jumlah & Nilai & & & & 643,5 \\
\hline
\end{tabular}

Nilai SUPR $-Q=\frac{\text { Jumlah Nilai Diperoleh }}{\text { Jumlah Nilai Maksimal }} \times 100 \%$

Nilai Maksimal $=$ Jumlah Item x Nilai Tertinggi $\mathrm{x}$ Jumlah Responden (8)

$$
=8 \times 5 \times 20
$$$$
=800
$$

Nilai SUPR $-Q=\frac{643,5}{800} \times 100 \%$

Nilai SUPR $-Q=80,44 \%$

Dari perhitungan di atas dihasilkan nilai persentase sebesar $80,44 \%$ dan masuk dalam kategori baik, dimana batas nilai minimalnya adalah 75\% [13].

\section{Reliability}

Pada tahapan reliability pada aplikasi sistem pendukung keputusan digunakan perangkat lunak WAPT versi 10.0. Simulasi pengujian menggunakan 20 user yang 
mengakses aplikasi, setiap 10 detik ada 2 user yang mengakses dengan durasi selama 60 menit. Hasil dari pengujian menggunakan aplikasi WAPT dengan total test case yang didapat sebanyak 13.960 page, total kegagalan page sebanyak 0, total hits 28.936 total kegagalan hits sebanyak 0. Dengan rumus perhitungan reliability Nelson.

$$
\begin{aligned}
& R=\frac{n-f}{n}=1-\frac{f}{n}=1-r \\
& R=\text { Reliability } \quad f=\text { Total Failure } \\
& n=\text { Total Test Case } \quad r=\text { Error Rate }
\end{aligned}
$$

Hasil perhitungan nilai reliability atau nilai R.

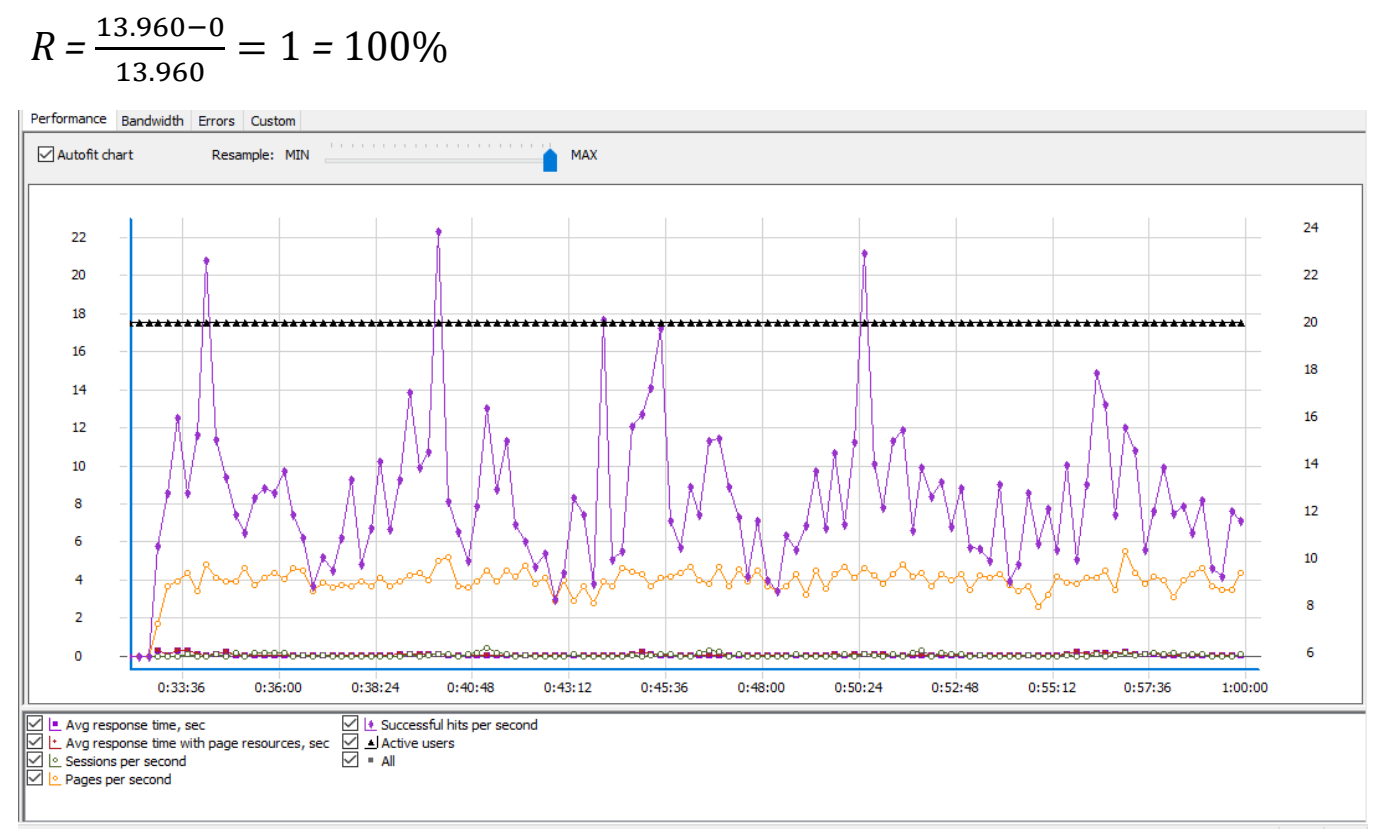

Gambar 5. Grafik hasil pengujian WAPT versi 10.0

Hasil dari pengujian tersebut dibandingkan dengan standar uji reliability dengan standar Telcordia dimana batas persentase dari aspek reliability adalah minimal 95\% [14].

\section{Portability}

Pada tahap pengujian portability dilakukan menggunakan berbagai macam lingkungan media browser yang digunakan, seperti browser Mozilla Firefox, Google Chrome dan Microsoft Edge. Pengujian dilakukan dengan 2 spesifikasi komputer yang berbeda, pengujian pertama dilakukan dengan spesifikasi computer.

Perangkat Keras

- Processor Intel Celeron N3350, SSD M.2 128 GB dan RAM 4 GB

Perangkat Lunak

- Windows 10 Home 64 Bit, Mozilla Firefox, Google Chrome dan Microsoft Edge

Pada pengujian dengan spesifikasi komputer di atas aplikasi dapat berjalan dengan lancar, untuk pengujian kedua dilakukan dengan spesifikasi computer.

1) Perangkat Keras 
Sistem Pendukung Keputusan Penentuan Prioritas Bantuan Kepada Warga Kurang

Mampu Menggunakan Teknik Analisis Hirarki Proses

\section{- Processor AMD A9, HDD 500 GB dan RAM 4 GB}

2) Perangkat Lunak

- Windows 10 Pro 64 Bit, Mozilla Firefox, Google Chrome dan Microsoft Edge.

Pada pengujian kedua dengan spesifikasi komputer dan browser yang berbeda seperti pada gambar di atas aplikasi dapat berjalan dengan lancar.

\section{SIMPULAN}

Pengambilan keputusan untuk menentukan prioritas penerima bantuan yang digunakan di Desa XYZ hanya berpatokan pada pengajuan dari RT dan RW saja tanpa adanya pertimbangan kriteria-kriteria untuk pengambilan keputusan sehingga rentan terjadinya kesalahan dalam memprioritaskan bantuan bagi warga yang lebih membutuhkan untuk segera mendapat bantuan tersebut. Dengan adanya sistem pendukung keputusan penentuan prioritas bantuan keluarga miskin menggunakan metode AHP di Desa XYZ penentuan prioritas penerima bantuan menjadi lebih efisien dan akurat. Berdasarkan hasil penelitian dalam pengembangan sistem pendukung keputusan penentuan prioritas penerima bantuan menggunakan metode AHP di Desa XYZ, Kecamatan Klapanunggal, Kabupaten Bogor maka dapat diambil beberapa kesimpulan sebagai berikut: 1) Aplikasi sistem pendukung keputusan penentuan prioritas penerima bantuan menggunakan metode AHP di Desa XYZ Kecamatan Klapanunggal Kabupaten Bogor membantu dalam proses penentuan prioritas penerima bantuan sehingga lebih efisien dalam pemilihan prioritas penerima bantuan bagi masyarakat khususnya masyarakat warga Desa XYZ. 2) Dengan aplikasi sistem pendukung keputusan multikriteria tersebut calon penerima bantuan akan disaring sesuai dengan tingkat kriteria keluarga miskin, sehingga dengan terbatasnya kuota bantuan dari pemerintah yang ada akan sangat membantu untuk mengurangi tingkat kesalahan pemberian bantuan terhadap masyarakat. 3) Pengujian sistem menggunakan ISO 25010, aplikasi pihak ketiga, dan juga 20 responden dari lingkungan yang berbeda, dari hasil pengujian tersebut aplikasi sistem pendukung keputusan penentuan prioritas penerima bantuan menggunakan metode AHP di Desa XYZ, Kecamatan Klapanunggal, Kabupaten Bogor masuk kedalam kategori "Baik" sehingga layak untuk digunakan sebagai alat untuk menentukan prioritas penerima bantuan di Kantor Desa XYZ.

\section{DAFTAR PUSTAKA}

[1] Suwandi, "Desentralisasi Fiskal dan Dampaknya terhadap Pertumbuhan Ekonomi, Penyerapan Tenaga Kerja, Kemiskinan, dan Kesejahteraan di Kabupaten/Kota Induk Provinsi Papua.," Deep. Yogyakarta, p. 80, 2015.

[2] H. H. Goh and B. C. Kok, "Application of analytic hierarchy process (AHP) in load shedding scheme for electrical power system," 2010 9th Conf. Environ. Electr. Eng. EEEIC 2010, pp. 365-368, 2010.

[3] H. Suaib, "Suku Moi: Nilai-Nilai Kearifan Lokal dan Modal Sosial dalam Pemberdayaan Masyarakat,” AnImage Tangerang, 2017.

[4] Kusrini, Konsep Dan Aplikasi Sistem Pendukung Keputusan. Yogyakarta: CV Andi 
Offset, 2007.

[5] E. Prahasta, Konsep-Konsep Dasar SIG. Informatika- Bandung, 2002.

[6] Kusrini, Konsep dan Aplikasi Sistem Pendukung Keputusan. Yogyakarta: Andi offset - Yogyakarta - p15, 2007.

[7] D. Nofriansyah, Konsep Data Mining Vs Sistem Pendukung Keputusan. Yogyakarta: Deepublish, 2015.

[8] H. Pratiwi, "Buku Ajar Sistem Pendukung Keputusan," Yogyakarta: Deepublish, 2016, p. 27.

[9] S. Lestari, "Penerapan Metode Weighted Product Model Untuk Seleksi Calon Karyawan," J. Sist. Inf., vol. 5, no. 1, pp. 540-545, 2013.

[10] G. Veeramalai, "Eigen Values of an Interval Matrix," vol. Volume 2, 2012.

[11] A. R. Howart, "Aljabar Linear Elementer," in Edisi Ke-8, Jakarta: Erlangga, 2004.

[12] H. Anton, “Aljabar Linear Elementer," in Edisi Ke-5, Jakarta: Erlangga, 1987.

[13] Sauro, Jeff, Lewis, and J. R, "Quantifying the User Experience: Practical Statistics fo User Research," Morgan Kaufmann, Burlingt., 2016.

[14] A. Asthana and J. Olivieri, "Quantifying Software Reliability and Readliness," IEEE, 2009. 